\title{
Smart Services for Managing Solitary Fall Death in a House of the Elderly Living Alone
}

\author{
Hyun Soo Lee and Sung Hee Lee
}

\begin{abstract}
With declining birth rates and rising life expectancy, population ageing is accelerating recently. As more and more elderly people live alone, it is generating a new social question of solitary death. The purpose of this paper is to suggest an intelligent residential service designed to prevent and manage solitary fall death in the house of the elderly people who live alone. It explains an intelligence service for promptly responding to emergency situations in the stages following an accident. Through an analysis of 1,745 behavioral patterns involving thirteen solitary elderly people based on the self-administered questionnaire that proceeded in earlier studies, we have focused on kitchen, which registered the highest space usage frequency, and proposed an organization of sensors and instruments needed for the intelligent service as well as the service process. This thesis is significant in that it presents and discusses a solution to the problem of solitary fall deaths through an analysis of behavioral patterns and by using IT. Besides, its contribution consists in suggesting a method for applying IT in a house through an analysis of the behavior of solitary seniors in the house and of the indoor environment.
\end{abstract}

Index Terms—Smart service, solitary, elderly, fall death.

\section{INTRODUCTION}

The number of seniors living alone is rapidly increasing amid fast aging trend, which could cause serious social issues. One of those issues is solitary death. In Japan, the fastest aging society in the world, around 30,000 people die alone each year [1]. Seniors with no supporting family are highly likely to die alone if they pass away suddenly [2]. Many seniors living alone are more likely to be isolated from the society. It is because they less frequently interact with others such as family members, friends and group members and receive much less support from others. As a result, the number of seniors who could face death with dignity is declining. According to Guse [3], successful aging is a result of interaction linked to heath, environment and society, rather than personal characteristics. However, seniors living alone are more likely to commit suicide, as they have little emotional ties with others due to rare social interaction. Also, they are more likely to suffer from chronic diseases due to physical aging than other seniors.

The problems of seniors living alone are not just a personal issue but a social issue that should be solved urgently on a national scale. However, solving the issue is no easy task, since it is more difficult to take care of seniors living alone

Manuscript received June 16, 2014; revised August 4, 2014. This work was supported in part by the National Research Foundation of Korea (NRF) grant funded by the Korea government(MSIP) (No. 2008-0061908).

The authors are with the Interior Architecture and Built Environment Department, Yonsei University, Seoul Republic of Korea (e-mail: hyunsoolee@yonsei.ac.kr). than other seniors. Without such active support, however, the last part of seniors' lives is very miserable. However, nursing the elderly living alone requires tremendous amount of manpower and budget. In reality, providing such support is not feasible. One of ways to solve such issue is 'smart residential services' using IT technology. Reducing social costs amid aging society requires establishing an environment where seniors can enjoy independent living. As many researchers including Madivin [4] argued, it is essential to offer various services for residential environment where seniors can live independent lives. The smart residential services are one of approaches to solving the aging issue in an effective manner. However, state-of-the-art equipment alone doesn't necessarily create an environment for senior residents. They become more satisfied when their residential space and human behaviors such as lifestyles are considered when creating the environment. Creating successful elderly-friendly houses with digital technology require applying user-oriented concepts. One of the alternatives is residential planning based on the behaviors of the elderly.

This study is aimed at presenting smart residential services to offer residential conveniences through IT technology. The problem with solitary death can be minimized by immediately dealing with seniors who collapsed or died. Also, the causes of solitary death should be analyzed and prevented to reduce solitary death. The leading causes of solitary death are diseases and residential accident. Among accidents facing seniors, falling represents the highest proportion. Therefore, falling accidents are closely related to residential services and space planning. To accurately identify the demand from residents to offer fall-managing services reflecting their demand, it is essential to analyze the behaviors of the elderly living alone. Since its goal is to offer customized services for users, analyzing the behaviors of seniors can reflect their demand more properly. The purpose of this study is to present smart residential services aimed at preventing and managing solitary death caused by falling accidents of seniors living alone, based on their behaviors.

\section{ReSEARCh Method}

This paper aims to propose an organization of sensors and instruments for an intelligent service and develop an intelligent service process on the basis of the major behavioral patterns of elderly people living alone who are likely to meet a solitary fall death by analyzing the circumstances before and after the behavioral patterns of solitary seniors based on the records of behaviors examined in earlier studies. Specifics of the used research method and scope are as follows. First, through related literature, I will 
figure out the characteristics of the solitary fall deaths of elderly people who live alone and examine the intelligent residential service. Second, by drawing on the results of the self-administered 24-hour questionnaire given in an earlier study, I will analyze the behavioral patterns of thirteen elderly people and their mainly used spaces. Third, I will propose an organization of sensors and instruments for an intelligent service designed to prevent and manage solitary death of elderly people who live alone by drawing on the behavioral patterns of elderly people with a focus on the principally used spaces. Lastly, I will develop an intelligent service process for managing solitary fall death in the house of elderly people who lived alone.

\section{RELATED WORKS}

\section{A. Solitary Fall Death}

The solitary death of elderly people who live alone is a serious social problem, as it threatens human dignity. It is not a question that can be handled by single individuals, so should not be left up to elderly people or their family. It is urgent to come up with a measure for preventing solitary deaths, which are on the increase. As far as solitary death is concerned, prevention is as important as post-accident handling. To prevent solitary deaths, we can think of various methods. Of the various methods, it is an important research issue to prevent solitary death from fall through safe management that prevents falls. As far as accidents in the house are concerned, fall is among the major causes of elderly deaths. According to Tinetti [5], a fall refers to collapsing down to the floor regardless of a person's intention. The Global Burden of Disease Project by WHO brings special attention to fall with the fact that in 2004 there were 424,000 fall deaths in the world. As a matter of fact, in the United States, in 2003 alone, 13,700 elderly people who were 65 or older suffered fall death. In Korea, one third of elderly people who are 65 or older and stay at home experience at least one fall a year [6]. An elderly person who suffers a fall may die from long-term disabilities or complications caused by fracture, parenchymal damage, reduced mobility etc. With advancing age, a person is likelier to suffer a fall. For ageing has much influence on the risk of falls. Elderly people frequently experience falls because they have their eye vision, sense of balance, and other abilities compromised. It was reported that more than half of those who have suffered falls before repeat their experience. Once a physical injury is caused by a fall, recovery is difficult and mobility is restricted. Even if actual physical injury is not inflicted, increased fear of another fall exerts negative influence on a person's physical and social functions. And this is further feared to cause unnecessarily increased dependence, lowered functions, social isolation, and depression, which could lower the quality of life. So, most studies on falls stress the importance of the environment in the house. No matter how well an environment is managed, however, all falls of elderly people cannot be completely prevented. So, an emergency communications network is needed to minimize a resident's injuries and avoid a longtime absence of care for the person in case of a fall. Development of a prompt intelligent management service that applies IT should be effective in preventing and managing falls [7].

TABLE I: INTERNAL AND EXTERNAL CAUSES OF AN ELDERLY PERSON'S

\begin{tabular}{|c|c|c|}
\hline \multicolumn{2}{|c|}{ Risk factor } & \multirow{2}{*}{$\begin{array}{l}\text { Description } \\
\text { Identification disorder, reduced field of vision, and } \\
\text { reduced adaptivity to changes in lighting }\end{array}$} \\
\hline $\begin{array}{l}\text { Internal } \\
\text { factor }\end{array}$ & $\begin{array}{l}\text { Lowered } \\
\text { visual } \\
\text { function }\end{array}$ & \\
\hline $\begin{array}{l}\text { Internal } \\
\text { factor }\end{array}$ & $\begin{array}{c}\text { Reduced } \\
\text { balance and } \\
\text { lowered } \\
\text { musculoskel } \\
\text { etal } \\
\text { functions }\end{array}$ & $\begin{array}{l}\text { - Level of activity, neurological symptoms, and } \\
\text { muscular strength and bone joint flexibility } \\
\text { influence maneuverability } \\
\text { - Feedbacks for vestibular system, eye vision, and } \\
\text { proprioceptive sense perform a key role in } \\
\text { maintaining balance and stability. } \\
\text { - Weakened lower extremity muscle strength } \\
\text { reduces pace and shortens strides. }\end{array}$ \\
\hline $\begin{array}{l}\text { Internal } \\
\text { factor }\end{array}$ & $\begin{array}{l}\text { Walking } \\
\text { abnormalitie } \\
\text { s from } \\
\text { chronic } \\
\text { diseases }\end{array}$ & $\begin{array}{l}\text { - Dementia: causes ataxia while influencing balance } \\
\text { and walking. } \\
\text { - Diabetes: influences lower extremity muscle } \\
\text { strength, reflex response, and sensory functions. } \\
\text { - Weakened ankle muscles and damaged sensory } \\
\text { functions of proprioceptive sense: causes } \\
\text { hemiplegic walking. } \\
\text { - Parkinson disease: causes difficulty in start and } \\
\text { stop of walking, short pace, and dragged feet. }\end{array}$ \\
\hline $\begin{array}{l}\text { Internal } \\
\text { factor }\end{array}$ & $\begin{array}{l}\text { Cardiovascul } \\
\text { ar diseases }\end{array}$ & $\begin{array}{l}\text { Cardiac arrhythmia, carotid tubercle, cerebral } \\
\text { perfusion etc. }\end{array}$ \\
\hline $\begin{array}{l}\text { Internal } \\
\text { factor }\end{array}$ & $\begin{array}{l}\text { Psychosocial } \\
\text { factor }\end{array}$ & $\begin{array}{l}\text { Fear derived from experience of a fall leads to } \\
\text { restricted activity, which increases risk of falls with } \\
\text { lowered muscle strength and enduring strength } \\
\text { caused by lack of activity. }\end{array}$ \\
\hline $\begin{array}{l}\text { Internal } \\
\text { factor }\end{array}$ & Medication & $\begin{array}{l}\text { Sedative, antipsychotic medication, diuretic, high } \\
\text { blood pressure medication, alcohol etc. influence } \\
\text { body adjustment, cerebral perfusion, cognitive } \\
\text { function etc. }\end{array}$ \\
\hline $\begin{array}{l}\text { External } \\
\text { factor }\end{array}$ & Obstacles & $\begin{array}{l}\text { Sedative, antipsychotic medication, diuretic, high } \\
\text { blood pressure medication, alcohol etc. influence } \\
\text { body adjustment, cerebral perfusion, cognitive } \\
\text { function etc. }\end{array}$ \\
\hline
\end{tabular}

Especially those elderly people who live alone in a poor residential environment need an intelligent service designed to prevent and manage their solitary fall death in the house, since currently there are insufficient safety devices provided against falls in the house. One may expect to cut down on medical costs for solitary elderly people through such an intelligent service. Elderly people who are 65 or older use $6 \%$ of their medical spending for unexpected injuries [8]. Minimum $40 \%$ of seniors are hospitalized from injuries from a fall, while $10 \%$ spend extra money for nursing case [9]-[11]. Falls in the house originates from the physical environment and the bodily factor of aging. Kim [12] explained that falls are influenced by various internal and external risks. Table I classifies risks related to falls into internal and external factors. The causes of falls as shown in the table should be figured out, because falls must be prevented through improvement of physical environment while prompt response needs to be provided in case a resident suffers a fall from his or her bodily causes.

Elderly people basically cannot avoid internal changes with diseases as their body ages, and even if they maintain their health, unexpected falls are unpreventable. Also, there is a limit to how one copes with accidental falls even if obstacles as external factors are removed through planning of 
physical environment. Therefore, research is needed on post-accident management designed to ensure a prompt response to a fall and thereby prevent a solitary death resulting from longtime neglect.

\section{B. Intelligent Residential Services}

Smart Home, meaning a house that comes with automation, is an intelligent house or IT house. Intelligent residential services consist in providing support to ensure automated and efficient use of various facilities in an intelligent house. For example, Hunhammar [13] suggests that an intelligent house should include control and management services such as energy saving, safety management, emergency management, crime prevention, and fire protection. Intelligent service consists in providing a residential service that uses IT with such features as situation recognition, real time, personalized, and sensing to sensitively recognize situations arising in every corner of a house and thereby promptly respond through analysis and prediction. With the development of IT, research is actively carried out on 'Internet of Things (IoT)' that can share information through wireless networking not only in various home electronics and electronic devices but also in various areas such as healthcare, remote meter reading, smart home, and smart car. IoT refers to intelligent technology and network service that provides mutual communication that deals with information between human and object, object and object [14]. IoT is helpful in more accurately and promptly figuring out a situation. For example, it makes it possible to improve the accuracy of decision-making through communication between CCTV and motion sensor, motion sensor and floor pressure sensor. One advantage of smart technology lies in saving much manpower involved in caring for elderly people by reducing their dependence on other people. To reduce dependence of elderly people, it is indispensable to provide appropriate services for them. So far, vitalization of smart home has been unsatisfactory, because it hasn't been able to provide appropriate services that consider its users. In this light, as regards provision of appropriate residential services, observation of elderly people's behaviors makes an effective method. Lee [15] suggested that we should fuse together in various ways inferential methods that are based on resident behaviors and services in order to predict and respond to complex human behaviors. In "Smart Homes for Patient at the End of Life, Demiris [16] presented types of monitoring such as functional monitoring, safety monitoring, physiological monitoring, and security monitoring. A description of monitoring should be helpful in conducting a systematic research. Specifics of monitoring are as seen in Table II. Types of monitoring may be explained as follows.

First, functional monitoring is about measuring activity in daily life and monitoring sleep quality. The behavioral analysis performed in this study is a kind of functional monitoring. Second, safety monitoring is designed to detect dangers such as gas leak, fire, and explosion. Third, physiological monitoring is concerned with measuring the physiological characteristics of elderly people and continually monitoring them for any sign of abnormalities. Fourth, security monitoring provides psychological stability by detecting a trespasser into the house of a solitary elderly person and providing crime prevention. Monitoring a resident's fall in the house requires sensors that can detect indoor environment and resident behaviors. A device for situational judgment must be installed to detect a fall through a sensor and thereby provide appropriate services that fit the specific situation. Sensors should be organized differently to specific purposes. Those sensors, which are needed to organize an intelligent service designed to detect specific situations like falls, should be applied to different purposes while causes of falls are considered and detection targets are clearly specified. From the perspective of an intelligent house alone, it is likely that various sensors are going to be installed. Yet, installing a large number of sensors is not necessarily good. It not only costs a lot but also requires much space for their installation. An appropriate number of sensors should be planned while considering cost and characteristics of a given space. Table III shows situation recognition sensors applied to indoor environment with a view to judging falls and motion detection sensors and instruments designed to judge falls based on a resident's behaviors.

TABLE II: ELEMENTS OF MONITORING SERVICE FOR ELDERLy PEOPLE WHO

\begin{tabular}{l|l}
\multicolumn{1}{c}{ Category } & \multicolumn{1}{c}{ LIVE ALONE } \\
\hline $\begin{array}{l}\text { Functional } \\
\text { monitoring }\end{array}$ & $\begin{array}{l}\text { Measures quality of everyday activities and } \\
\text { sleep. }\end{array}$ \\
\hline Safety monitoring & $\begin{array}{l}\text { Detects environmental dangers such as gas } \\
\text { leak, fire, and explosion. }\end{array}$ \\
\hline $\begin{array}{l}\text { Physiological } \\
\text { monitoring }\end{array}$ & $\begin{array}{l}\text { Measures physiological characteristics through } \\
\text { vital signs. }\end{array}$ \\
\hline Security monitoring & Detects and alerts threats such as trespasser. \\
\hline
\end{tabular}

In developing an intelligent residential service, sensor configuration enables smart home service. It is what we suggest in this paper based on the results of the study by Lee [17], who proposed various sensor organizations grounded on a scenario created from the perspective of users as solitary residents. It may sound plausible to install many of the sensors and instruments presented on Table III. But, an organization of sensors has to be decided while considering various factors such as budget, space for installation, and the psychology of elderly people. In this paper, we are going to describe an intelligent service for managing solitary fall death based on the data on elderly people who live alone with a focus on the above-classified sensors and instruments

\section{ANALysis OF RESIDENT BEHAVIOR}

\section{A. Major Behavioral Patterns for Elderly People Living Alone}

This paper is mainly concerned to suggest a service by analyzing resident behavior and integrating the results of the analysis and those of a scrutiny of related literature. In this paper, we are patterning the behavior of elderly people who live alone, because we want to provide a service that is more automated but ultimately customized to individuals. Elderly people basically have difficulty walking, as their sense of balance is compromised by their bodily aging. 
TABLE III: INTELLIGENT SERVICE SENSORS AND INSTRUMENTS FOR

\begin{tabular}{c|c|c|c} 
Category & Purpose & $\begin{array}{c}\text { Sensor and } \\
\text { instrument }\end{array}$ & \multicolumn{1}{|c}{ Description } \\
\hline $\begin{array}{c}\text { Situation } \\
\text { recognition }\end{array}$ & Fall & $\begin{array}{l}\text { Floor } \\
\text { pressure } \\
\text { sensor } \\
\text { gait of a resident by } \\
\text { monitoring the pressure } \\
\text { from the resident's walk } \\
\text { and detects big shocks } \\
\text { or abnormal levels of } \\
\text { pressure. }\end{array}$ \\
\hline
\end{tabular}

\begin{tabular}{|c|c|c|c|}
\hline $\begin{array}{l}\text { Situation } \\
\text { recognition }\end{array}$ & Fall & $\begin{array}{l}\text { Acceleration } \\
\text { sensor } \\
\text { (vibration } \\
\text { sensor) }\end{array}$ & $\begin{array}{l}\text { Being able to perform } \\
\text { real-time monitoring by } \\
\text { analyzing the quantity } \\
\text { of motion through } \\
\text { counting a resident' } \\
\text { steps in indoor } \\
\text { environment, the sensor } \\
\text { can check the resident's } \\
\text { health condition and } \\
\text { detects suspected falls. }\end{array}$ \\
\hline $\begin{array}{l}\text { Situation } \\
\text { recognition }\end{array}$ & Fall & $\begin{array}{l}\text { Sound } \\
\text { detection } \\
\text { sensor } \\
\text { (microphon) }\end{array}$ & $\begin{array}{l}\text { When a fall occurs and } \\
\text { movement is not active } \\
\text { from fracture etc., the } \\
\text { sensor detects a distress } \\
\text { call from a resident. }\end{array}$ \\
\hline $\begin{array}{l}\text { Situation } \\
\text { recognition }\end{array}$ & $\begin{array}{c}\text { Indoor } \\
\text { environment }\end{array}$ & $\begin{array}{c}\text { Auto-on } \\
\text { light }\end{array}$ & $\begin{array}{l}\text { Tracing a resident's line } \\
\text { of movement, the } \\
\text { lighting fixture } \\
\text { automatically switches } \\
\text { on or off to prevent the } \\
\text { resident's fall due to } \\
\text { dark indoor space. }\end{array}$ \\
\hline $\begin{array}{l}\text { Situation } \\
\text { recognition }\end{array}$ & $\begin{array}{l}\text { Indoor } \\
\text { environment }\end{array}$ & $\begin{array}{l}\text { Customized } \\
\text { interior } \\
\text { lighting } \\
\text { control } \\
\text { (dimming) }\end{array}$ & $\begin{array}{l}\text { Besides energy saving } \\
\text { through automatic } \\
\text { adjustment of luminous } \\
\text { intensity to outside } \\
\text { brightness, it keeps } \\
\text { adequate level of } \\
\text { brightness to prevent a } \\
\text { fall due to dazzling } \\
\text { light. }\end{array}$ \\
\hline $\begin{array}{c}\text { Behavioral } \\
\text { detection }\end{array}$ & $\begin{array}{l}\text { Resident } \\
\text { behavior }\end{array}$ & $\begin{array}{l}\text { Infrared } \\
\text { sensor (PIR } \\
\text { sensor) }\end{array}$ & $\begin{array}{l}\text { While data on a } \\
\text { resident's normal } \\
\text { behavior in the house is } \\
\text { collected through } \\
\text { infrared sensor, } \\
\text { ultrasound locating } \\
\text { sensor, wireless motion } \\
\text { sensor, RFID, motion } \\
\text { detection sensor, floor } \\
\text { presure sensor, and } \\
\text { smart carpet, data is } \\
\text { accumulated with a } \\
\text { view to developing the } \\
\text { resident-customized } \\
\text { intelligent service. }\end{array}$ \\
\hline $\begin{array}{c}\text { Behavioral } \\
\text { detection }\end{array}$ & $\begin{array}{l}\text { Resident } \\
\text { behavior }\end{array}$ & $\begin{array}{l}\text { Ultrasound } \\
\text { locating }\end{array}$ & $\begin{array}{l}\text { While data on a } \\
\text { resident's normal } \\
\text { behavior in the house is } \\
\text { collected through } \\
\text { infrared sensor, } \\
\text { ultrasound locating } \\
\text { sensor, wireless motion } \\
\text { sensor, RFID, motion } \\
\text { detection sensor, floor } \\
\text { presure sensor, and } \\
\text { smart carpet, data is } \\
\text { accumulated with a } \\
\text { view to developing the } \\
\text { resident-customized } \\
\text { intelligent service. }\end{array}$ \\
\hline $\begin{array}{c}\text { Behavioral } \\
\text { detection }\end{array}$ & $\begin{array}{l}\text { Resident } \\
\text { behavior }\end{array}$ & $\begin{array}{l}\text { Wireless } \\
\text { motion } \\
\text { sensor }\end{array}$ & $\begin{array}{l}\text { While data on a } \\
\text { resident's normal } \\
\text { behavior in the house is }\end{array}$ \\
\hline
\end{tabular}

\begin{tabular}{|c|c|c|c|}
\hline & & & $\begin{array}{l}\text { collected through } \\
\text { infrared sensor, } \\
\text { ultrasound locating } \\
\text { sensor, wireless motion } \\
\text { sensor, RFID, motion } \\
\text { detection sensor, floor } \\
\text { presure sensor, and } \\
\text { smart carpet, data is } \\
\text { accumulated with a } \\
\text { view to developing the } \\
\text { resident-customized } \\
\text { intelligent service. }\end{array}$ \\
\hline $\begin{array}{c}\text { Behavioral } \\
\text { detection }\end{array}$ & $\begin{array}{l}\text { Resident } \\
\text { behavior }\end{array}$ & RFID & $\begin{array}{l}\text { While data on a } \\
\text { resident's normal } \\
\text { behavior in the house is } \\
\text { collected through } \\
\text { infrared sensor, } \\
\text { ultrasound locating } \\
\text { sensor, wireless motion } \\
\text { sensor, RFID, motion } \\
\text { detection sensor, floor } \\
\text { presure sensor, and } \\
\text { smart carpet, data is } \\
\text { accumulated with a } \\
\text { view to developing the } \\
\text { resident-customized } \\
\text { intelligent service. }\end{array}$ \\
\hline $\begin{array}{c}\text { Behavioral } \\
\text { detection }\end{array}$ & $\begin{array}{l}\text { Resident } \\
\text { behavior }\end{array}$ & $\begin{array}{l}\text { Motion } \\
\text { detection } \\
\text { sensor } \\
\text { (motion } \\
\text { detection) }\end{array}$ & $\begin{array}{l}\text { While data on a } \\
\text { resident's normal } \\
\text { behavior in the house is } \\
\text { collected through } \\
\text { infrared sensor, } \\
\text { ultrasound locating } \\
\text { sensor, wireless motion } \\
\text { sensor, RFID, motion } \\
\text { detection sensor, floor } \\
\text { presure sensor, and } \\
\text { smart carpet, data is } \\
\text { accumulated with a } \\
\text { view to developing the } \\
\text { resident-customized } \\
\text { intelligent service. }\end{array}$ \\
\hline $\begin{array}{c}\text { Behavioral } \\
\text { detection }\end{array}$ & $\begin{array}{l}\text { Resident } \\
\text { behavior }\end{array}$ & $\begin{array}{c}\text { Floor } \\
\text { pressure } \\
\text { sensor }\end{array}$ & $\begin{array}{l}\text { While data on a } \\
\text { resident's normal } \\
\text { behavior in the house is } \\
\text { collected through } \\
\text { infrared sensor, } \\
\text { ultrasound locating } \\
\text { sensor, wireless motion } \\
\text { sensor, RFID, motion } \\
\text { detection sensor, floor } \\
\text { presure sensor, and } \\
\text { smart carpet, data is } \\
\text { accumulated with a } \\
\text { view to developing the } \\
\text { resident-customized } \\
\text { intelligent service. }\end{array}$ \\
\hline $\begin{array}{c}\text { Behavioral } \\
\text { detection }\end{array}$ & $\begin{array}{l}\text { Resident } \\
\text { behavior }\end{array}$ & Smart carpet & $\begin{array}{l}\text { While data on a } \\
\text { resident's normal } \\
\text { behavior in the house is } \\
\text { collected through } \\
\text { infrared sensor, } \\
\text { ultrasound locating } \\
\text { sensor, wireless motion } \\
\text { sensor, RFID, motion } \\
\text { detection sensor, floor } \\
\text { presure sensor, and } \\
\text { smart carpet, data is } \\
\text { accumulated with a } \\
\text { view to developing the } \\
\text { resident-customized } \\
\text { intelligent service. }\end{array}$ \\
\hline $\begin{array}{c}\text { Behavioral } \\
\text { detection }\end{array}$ & $\begin{array}{l}\text { Resident } \\
\text { behavior }\end{array}$ & CCTV & $\begin{array}{ll}\text { While data on a } \\
\text { resident's normal } \\
\text { behavior in the house is } \\
\text { collected through }\end{array}$ \\
\hline
\end{tabular}




\begin{tabular}{|c|c|c|c|}
\hline & & & $\begin{array}{l}\text { infrared sensor, } \\
\text { ultrasound locating } \\
\text { sensor, wireless motion } \\
\text { sensor, RFID, motion } \\
\text { detection sensor, floor } \\
\text { presure sensor, and } \\
\text { smart carpet, data is } \\
\text { accumulated with a } \\
\text { view to developing the } \\
\text { resident-customized } \\
\text { intelligent service. }\end{array}$ \\
\hline $\begin{array}{c}\text { Behavioral } \\
\text { detection }\end{array}$ & $\begin{array}{l}\text { Resident } \\
\text { behavior }\end{array}$ & $\begin{array}{l}\text { Emergency } \\
\text { caller }\end{array}$ & $\begin{array}{l}\text { While data on a } \\
\text { resident's normal } \\
\text { behavior in the house is } \\
\text { collected through } \\
\text { infrared sensor, } \\
\text { ultrasound locating } \\
\text { sensor, wireless motion } \\
\text { sensor, RFID, motion } \\
\text { detection sensor, floor } \\
\text { presure sensor, and } \\
\text { smart carpet, data is } \\
\text { accumulated with a } \\
\text { view to developing the } \\
\text { resident-customized } \\
\text { intelligent service. }\end{array}$ \\
\hline $\begin{array}{l}\text { Emergency } \\
\text { response }\end{array}$ & $\begin{array}{l}\text { Emergency } \\
\text { call }\end{array}$ & $\begin{array}{l}\text { Portable } \\
\text { emergency } \\
\text { caller }\end{array}$ & $\begin{array}{l}\text { The instrument first } \\
\text { uses sensors to scan } \\
\text { signs of abnormalities } \\
\text { in the indoor } \\
\text { environment and judge } \\
\text { whether a fall has } \\
\text { occurred, before it alerts } \\
\text { the specific emergency } \\
\text { to those involved } \\
\text { outside. }\end{array}$ \\
\hline
\end{tabular}

Furthermore, falls occur because of other mediating factors such as poor physical environment and obstacles. Those elderly people who spend relatively much time in the house can experience accidents in their habitually repeated behavioral patterns, so intensive attention needs to be given to the major behavioral patterns and space usage patterns, extracted based on frequency [18], [19]. If one uses certain patterns that indicate a resident's behavior, one gets to find it easier to provide efficient services desired by the resident [7]. For example, the analysis performed by Guerra-Santin [20] of the profound relationship between energy consumption and resident behavior comes close to the point that this paper builds on. It is because of the results that acknowledged the importance of behavior that this paper figures out the behavioral patterns which solitary elderly people frequently repeat in the house and uses the content of the self-administered questionnaire employed in the earlier study to get at the most frequently used spaces [7], [21]. In this study, we have come up with spaces that show behavioral patterns continuing to other behaviors based on behavioral records surveyed in earlier studies and by using the data on the behaviors of thirteen elderly people who love alone. Table IV shows major behavioral patterns and space usage patterns based on frequency and involving elderly people who live alone. As shown on Table V, the major behavioral pattern discovered in this paper (meal preparation and kitchen arrangement - dining) takes place in the spatial pattern (kitchen - dining area). This suggests that much of elderly people's behavior proceeds in the kitchen and in consequence, falls are likely to take place in the kitchen. Now, we are going to discuss the specifics of the residential service with a view to solving the issue of falls occurring during kitchen arrangement and dining in the kitchen area.

TABLE IV: Behavioral PATterns AND Space Usage PATternS

\begin{tabular}{|c|c|c|c|}
\hline Time slot & Behavioral pattern & $\begin{array}{l}\text { Space usage } \\
\text { pattern }\end{array}$ & Frequency \\
\hline 06:00-07:00 & Sleep-Wakeup & $\begin{array}{l}\text { Bedroom - } \\
\text { bedroom }\end{array}$ & 10 \\
\hline 06:00-07:00 & $\begin{array}{c}\text { Personal hygiene (defecation } \\
\text { and face washing) - meal } \\
\text { preparation and kitchen } \\
\text { arrangement }\end{array}$ & $\begin{array}{l}\text { Kitchen - } \\
\text { kitchen }\end{array}$ & 7 \\
\hline 06:00-07:00 & $\begin{array}{l}\text { Meal preparation and kitchen } \\
\text { arrangement - dining }\end{array}$ & $\begin{array}{l}\text { Kitchen - } \\
\text { kitchen }\end{array}$ & 5 \\
\hline 06:00-07:00 & $\begin{array}{l}\text { Religious activities (prayer, } \\
\text { Bible reading etc.) - personal } \\
\text { hygiene }\end{array}$ & $\begin{array}{l}\text { Bedroom - } \\
\text { kitchen }\end{array}$ & 5 \\
\hline 07:00-08:00 & $\begin{array}{l}\text { Meal preparation and kitchen } \\
\text { arrangement - dining }\end{array}$ & $\begin{array}{l}\text { Kitchen - } \\
\text { kitchen }\end{array}$ & 13 \\
\hline 07:00-08:00 & $\begin{array}{l}\text { Dining - meal preparation and } \\
\text { kitchen arrangement }\end{array}$ & $\begin{array}{l}\text { Kitchen - } \\
\text { kitchen }\end{array}$ & 9 \\
\hline 07:00-08:00 & $\begin{array}{l}\text { Personal hygiene (defecation } \\
\text { and face washing) - meal } \\
\text { preparation and kitchen } \\
\text { arrangement }\end{array}$ & $\begin{array}{l}\text { Bathroom - } \\
\text { ktichen }\end{array}$ & 6 \\
\hline 07:00-08:00 & $\begin{array}{l}\text { Personal hygiene (defecation } \\
\text { and face washing) - dining }\end{array}$ & $\begin{array}{l}\text { Bathroom - } \\
\text { kitchen }\end{array}$ & 5 \\
\hline 08:00-09:00 & $\begin{array}{l}\text { Meal preparation and kitchen } \\
\text { arrangement - dining }\end{array}$ & $\begin{array}{l}\text { Kitchen - } \\
\text { kitchen }\end{array}$ & 10 \\
\hline 08:00-09:00 & Dining - media (watch TV) & $\begin{array}{l}\text { Kitchen - } \\
\text { living room }\end{array}$ & 7 \\
\hline 08:00-09:00 & $\begin{array}{c}\text { Bath - meal preparation and } \\
\text { kitchen arrangement }\end{array}$ & $\begin{array}{l}\text { Bathroom - } \\
\text { kitchen }\end{array}$ & 5 \\
\hline 09:00-10:00 & $\begin{array}{l}\text { Meal preparation and kitchen } \\
\text { arrangement - media (watch } \\
\text { TV) }\end{array}$ & $\begin{array}{l}\text { Kitchen - } \\
\text { living room }\end{array}$ & 5 \\
\hline $16: 00-17: 00$ & $\begin{array}{l}\text { Media (listen to radio) - media } \\
\text { (watch TV) }\end{array}$ & $\begin{array}{c}\text { Ling room } \\
\text { - living } \\
\text { room }\end{array}$ & 5 \\
\hline 17:00-18:00 & $\begin{array}{l}\text { Meal preparation and kitchen } \\
\text { arrangement - dining }\end{array}$ & $\begin{array}{l}\text { Kitchen - } \\
\text { kitchen }\end{array}$ & 10 \\
\hline 17:00-18:00 & $\begin{array}{l}\text { Media (watch TV) - meal } \\
\text { preparation and kitchen } \\
\text { arrangement }\end{array}$ & $\begin{array}{l}\text { Living room } \\
\text { - kitchen }\end{array}$ & 8 \\
\hline 18:00-19:00 & $\begin{array}{l}\text { Meal preparation and kitchen } \\
\text { arrangement - dining }\end{array}$ & $\begin{array}{l}\text { Kitchen - } \\
\text { kitchen }\end{array}$ & 27 \\
\hline 18:00-19:00 & $\begin{array}{c}\text { Dining - meal preparation and } \\
\text { kitchen arrangement }\end{array}$ & $\begin{array}{c}\text { Kitchen - } \\
\text { kitchen }\end{array}$ & 14 \\
\hline 18:00-19:00 & Dining - media (watch TV) & $\begin{array}{l}\text { Kitchen - } \\
\text { living room }\end{array}$ & 10 \\
\hline 18:00-19:00 & $\begin{array}{l}\text { Meal preparation and kitchen } \\
\text { arrangement - media (watch } \\
\text { TV) }\end{array}$ & $\begin{array}{l}\text { Kitchen - } \\
\text { living room }\end{array}$ & 8 \\
\hline 19:00-20:00 & $\begin{array}{l}\text { Dining - meal preparation and } \\
\text { kitchen arrangement }\end{array}$ & $\begin{array}{l}\text { Kitchen - } \\
\text { kitchen }\end{array}$ & 11 \\
\hline 19:00-20:00 & $\begin{array}{l}\text { Meal preparation and kitchen } \\
\text { arrangement - dining }\end{array}$ & $\begin{array}{l}\text { Kitchen - } \\
\text { kitchen }\end{array}$ & 8 \\
\hline 20:00-21:00 & Media (watch TV) - sleep & $\begin{array}{l}\text { Living room } \\
\text { - bedroom }\end{array}$ & 5 \\
\hline 21:00-22:00 & Media (watch TV) - sleep & $\begin{array}{l}\text { Living room } \\
\text { - bedroom }\end{array}$ & 10 \\
\hline $22: 00-23: 00$ & Media (watch TV) - sleep & $\begin{array}{l}\text { Living room } \\
\text { - bedroom }\end{array}$ & 10 \\
\hline 22:00-23:00 & Media (watch TV) - Personal & Living room & 8 \\
\hline
\end{tabular}




\begin{tabular}{|c|c|c|c|}
\hline & $\begin{array}{c}\text { hygiene (defecation and face } \\
\text { washing) }\end{array}$ & - bathroom & \\
\hline $22: 00-23: 00$ & Media (watch TV) - sleep & $\begin{array}{l}\text { Living room } \\
\text { - bedroom }\end{array}$ & 5 \\
\hline 23:00-24:00 & Media (watch TV) - sleep & $\begin{array}{l}\text { Living room } \\
\text { - bedroom }\end{array}$ & 11 \\
\hline $23: 00-24: 00$ & $\begin{array}{l}\text { Personal hygiene (defecation } \\
\text { and face washing) - sleep }\end{array}$ & $\begin{array}{c}\text { Bathroom - } \\
\text { bedroom }\end{array}$ & 10 \\
\hline 23:00-24:00 & $\begin{array}{c}\text { Sleep - personal hygiene } \\
\text { (defecation and face washing) }\end{array}$ & $\begin{array}{l}\text { Bedroom - } \\
\text { bathroom }\end{array}$ & 5 \\
\hline 24:00-01:00 & $\begin{array}{c}\text { Sleep - personal hygiene } \\
\text { (defecation and face washing) }\end{array}$ & $\begin{array}{l}\text { Bedroom - } \\
\text { bathroom }\end{array}$ & 5 \\
\hline 24:00-01:00 & $\begin{array}{l}\text { Personal hygiene (defecation } \\
\text { and face washing) - sleep }\end{array}$ & $\begin{array}{l}\text { Bathroom - } \\
\text { bedroom }\end{array}$ & 5 \\
\hline 01:00-02:00 & $\begin{array}{l}\text { Personal hygiene (defecation } \\
\text { and face washing) - sleep }\end{array}$ & $\begin{array}{c}\text { Bathroom - } \\
\text { bedroom }\end{array}$ & 10 \\
\hline 01:00-02:00 & $\begin{array}{c}\text { Sleep - personal hygiene } \\
\text { (defecation and face washing) }\end{array}$ & $\begin{array}{l}\text { Bedroom - } \\
\text { bathroom }\end{array}$ & 8 \\
\hline 02:00-03:00 & $\begin{array}{c}\text { Sleep - personal hygiene } \\
\text { (defecation and face washing) }\end{array}$ & $\begin{array}{l}\text { Bedroom - } \\
\text { bathroom }\end{array}$ & 11 \\
\hline 02:00-03:00 & $\begin{array}{l}\text { Personal hygiene (defecation } \\
\text { and face washing) - sleep }\end{array}$ & $\begin{array}{c}\text { Bathroom - } \\
\text { bedroom }\end{array}$ & 7 \\
\hline 02:00-03:00 & $\begin{array}{c}\text { Sleep - wakeful sleep, having } \\
\text { difficulty sleeping }\end{array}$ & $\begin{array}{l}\text { Bedroom - } \\
\text { bedroom }\end{array}$ & 5 \\
\hline 03:00-04:00 & $\begin{array}{c}\text { Sleep - personal hygiene } \\
\text { (defecation and face washing) }\end{array}$ & $\begin{array}{l}\text { Bedroom - } \\
\text { bathroom }\end{array}$ & 6 \\
\hline 03:00-04:00 & $\begin{array}{c}\text { Sleep - personal hygiene } \\
\text { (defecation and face washing) }\end{array}$ & $\begin{array}{l}\text { Bedroom - } \\
\text { bathroom }\end{array}$ & 5 \\
\hline 04:00-05:00 & Sleep - wakeup & $\begin{array}{l}\text { Bedroom - } \\
\text { bedroom }\end{array}$ & 14 \\
\hline 04:00-05:00 & $\begin{array}{c}\text { Sleep - personal hygiene } \\
\text { (defecation and face washing) }\end{array}$ & $\begin{array}{l}\text { Bedroom - } \\
\text { bathroom }\end{array}$ & 9 \\
\hline 04:00-05:00 & $\begin{array}{l}\text { Personal hygiene (defecation } \\
\text { and face washing) - sleep }\end{array}$ & $\begin{array}{l}\text { Bathroom - } \\
\text { bedroom }\end{array}$ & 6 \\
\hline 04:00-05:00 & $\begin{array}{c}\text { Personal hygiene (defecation } \\
\text { and face washing) - religious } \\
\text { activities }\end{array}$ & $\begin{array}{l}\text { Bedroom - } \\
\text { living room }\end{array}$ & 6 \\
\hline 05:00-06:00 & Sleep - wakeup & $\begin{array}{l}\text { Bedroom - } \\
\text { bedroom }\end{array}$ & 7 \\
\hline
\end{tabular}

\section{B. Analysis of Circumstances before and after Behavioral Patterns}

This paper assumes that it may be important to know the circumstances before and after major behavioral patterns in presenting an appropriate residential service. On this assumption, we have analyzed the major behavioral pattern (meal preparation and kitchen arrangement - dining) seen between 6 p.m. and 7 p.m. in the space usage pattern for the time slot between 5 p.m. and 8 p.m., which adds an hour each before and after. As a result, we have come up with total thirty-one cases that showed relevant behavioral patterns among thirteen elderly people who lived alone. Table VI shows the analysis of the space usage pattern before and after the major behavioral patterns in relation to the thirty-one cases. It shows the analysis of the space usage pattern before and after the major behavioral patterns. Seeing resident behaviors not separately but as continuity constitutes the basis for proposing an appropriate service.

TABLE V: Summary of Behavioral PatTERnS AND SpaCE UsAgE PATTERNS

\begin{tabular}{|l|l|c|c|}
\hline Behavioral pattern & Frequency & $\begin{array}{c}\text { Space usage } \\
\text { pattern }\end{array}$ & Frequency \\
\hline
\end{tabular}

\begin{tabular}{|c|c|c|c|}
\hline $\begin{array}{l}\text { Meal preparation and } \\
\text { kitchen arrangement - } \\
\text { dining }\end{array}$ & 73 & $\begin{array}{l}\text { Kitchen - } \\
\text { kitchen }\end{array}$ & 107 \\
\hline $\begin{array}{l}\text { Sleep - personal hygiene } \\
\text { (defecation and face } \\
\text { washing) }\end{array}$ & 49 & $\begin{array}{l}\text { Bedroom - } \\
\text { bathroom }\end{array}$ & 49 \\
\hline Media (watch TV) - sleep & 41 & $\begin{array}{l}\text { Living room - } \\
\text { bedroom }\end{array}$ & 41 \\
\hline $\begin{array}{l}\text { Personal hygiene } \\
\text { (defecation and face } \\
\text { washing) - sleep }\end{array}$ & 38 & $\begin{array}{l}\text { Bathroom - } \\
\text { bedroom }\end{array}$ & 38 \\
\hline $\begin{array}{l}\text { Dining - meal preparation } \\
\text { and kitchen arrangement }\end{array}$ & 34 & $\begin{array}{l}\text { Bedroom - } \\
\text { bedroom }\end{array}$ & 36 \\
\hline Sleep - wakeup & 31 & Kitch - bedroom & 30 \\
\hline $\begin{array}{c}\text { Dining - media (watch } \\
\text { TV) }\end{array}$ & 17 & $\begin{array}{l}\text { Bathroom - } \\
\text { kitchen }\end{array}$ & 23 \\
\hline $\begin{array}{c}\text { Personal hygiene } \\
\text { (defecation and face } \\
\text { washing) - meal } \\
\text { preparation and kitchen } \\
\text { arrangement }\end{array}$ & 13 & $\begin{array}{l}\text { Living room - } \\
\text { bathroom }\end{array}$ & 13 \\
\hline $\begin{array}{l}\text { Meal preparation and } \\
\text { kitchen arrangement - } \\
\text { media (watch TV) }\end{array}$ & 13 & $\begin{array}{l}\text { Living room - } \\
\text { kitchen }\end{array}$ & 8 \\
\hline $\begin{array}{l}\text { Media (watch TV) - } \\
\text { personal hygiene } \\
\text { (defecation and face } \\
\text { washing) }\end{array}$ & 8 & $\begin{array}{l}\text { bathroom - } \\
\text { living room }\end{array}$ & 6 \\
\hline $\begin{array}{l}\text { Media (watch TV) - meal } \\
\text { preparation and kitchen } \\
\text { arrangement }\end{array}$ & 8 & $\begin{array}{l}\text { Living room- } \\
\text { living room }\end{array}$ & 5 \\
\hline
\end{tabular}

TABLE VI: ANALysis of SPACE USAge PATterns Before AdD AFTER MAJOR BeHAVIORAL PATTERNS

\begin{tabular}{|c|c|c|}
\hline Space usage pattern & \multicolumn{2}{|c|}{ Frequency } \\
\hline $\begin{array}{l}\text { Living room } \rightarrow[\text { Meal preparation and } \\
\text { kitchen arrangement - dining }] \rightarrow \text { kitchen }\end{array}$ & \multicolumn{2}{|l|}{12} \\
\hline $\begin{array}{c}\text { Living room } \rightarrow \text { [Meal preparation and } \\
\text { kitchen arrangement - dining }] \rightarrow \text { kitchen }\end{array}$ & \multicolumn{2}{|l|}{7} \\
\hline $\begin{array}{l}\text { Outside } \rightarrow \text { [Meal preparation and kitchen } \\
\text { arrangement - dining }] \rightarrow \text { living room }\end{array}$ & \multicolumn{2}{|l|}{3} \\
\hline $\begin{array}{l}\text { Bedroom } \rightarrow \text { [Meal preparation and kitchen } \\
\text { arrangement - dining }] \rightarrow \text { kitchen }\end{array}$ & \multicolumn{2}{|l|}{2} \\
\hline $\begin{array}{l}\text { Living room } \rightarrow[\text { Meal preparation and } \\
\text { kitchen arrangement - dining }] \rightarrow \text { bathroom }\end{array}$ & \multicolumn{2}{|l|}{2} \\
\hline $\begin{array}{l}\text { Bathroom } \rightarrow \text { [Meal preparation and kitchen } \\
\text { arrangement - dining }] \rightarrow \text { kitchen }\end{array}$ & \multicolumn{2}{|l|}{1} \\
\hline $\begin{array}{l}\text { Bathroom } \rightarrow \text { [Meal preparation and kitchen } \\
\quad \text { arrangement - dining }] \rightarrow \text { outside }\end{array}$ & \multicolumn{2}{|l|}{1} \\
\hline $\begin{array}{l}\text { Bedroom } \rightarrow \text { [Meal preparation and kitchen } \\
\text { arrangement - dining }] \rightarrow \text { bedroom }\end{array}$ & \multicolumn{2}{|l|}{1} \\
\hline $\begin{array}{l}\text { Outside } \rightarrow \text { [Meal preparation and kitchen } \\
\text { arrangement - dining }] \rightarrow \text { kitchen }\end{array}$ & \multicolumn{2}{|l|}{1} \\
\hline $\begin{array}{l}\text { Outside } \rightarrow \text { [Meal preparation and kitchen } \\
\text { arrangement - dining }] \rightarrow \text { Outside }\end{array}$ & \multicolumn{2}{|l|}{1} \\
\hline Total & \multicolumn{2}{|l|}{31} \\
\hline Expansion of major space usage patters & \multicolumn{2}{|c|}{ Frequency } \\
\hline $\begin{array}{l}\text { Living room } \rightarrow \text { [Meal preparation and } \\
\text { kitchen arrangement - dining] } \rightarrow \text { kitchen }\end{array}$ & $\rightarrow$ Living room & 8 \\
\hline $\begin{array}{l}\text { Living room } \rightarrow[\text { Meal preparation and } \\
\text { kitchen arrangement - dining }] \rightarrow \text { kitchen }\end{array}$ & $\rightarrow$ Bedroom & 2 \\
\hline $\begin{array}{l}\text { Living room } \rightarrow[\text { Meal preparation and } \\
\text { kitchen arrangement - dining }] \rightarrow \text { kitchen }\end{array}$ & $\rightarrow$ Bathroom & 1 \\
\hline $\begin{array}{c}\text { Living room } \rightarrow \text { [Meal preparation and } \\
\text { kitchen arrangement - dining }] \rightarrow \text { kitchen }\end{array}$ & $\rightarrow$ Outside & 1 \\
\hline Total & \multicolumn{2}{|l|}{12} \\
\hline
\end{tabular}

When we analyzed thirty-one cases within the time frame 
between 5 p.m. and 8 p.m. which adds an hour each before and after the major behavioral pattern, the space usage pattern of "Living room - kitchen - kitchen - kitchen" registered the highest frequency of 12 . When we expanded the space usage pattern in mobility for a look, the space usage pattern of "Living room - kitchen - kitchen - kitchen living room" registered the highest frequency of 8 . Thus, analysis of the space usage pattern as discerned in the paper is significant in that it has set the importance of space-specific services. The habitually repeated behavioral patterns are likelier to run into accidents. In this respect, behavioral patterns are significant. Especially considering the major behavioral pattern (meal preparation and kitchen arrangement - dining), a possibly provided service should be a specific service that considers resident behavior in the kitchen and the circumstances before and after.

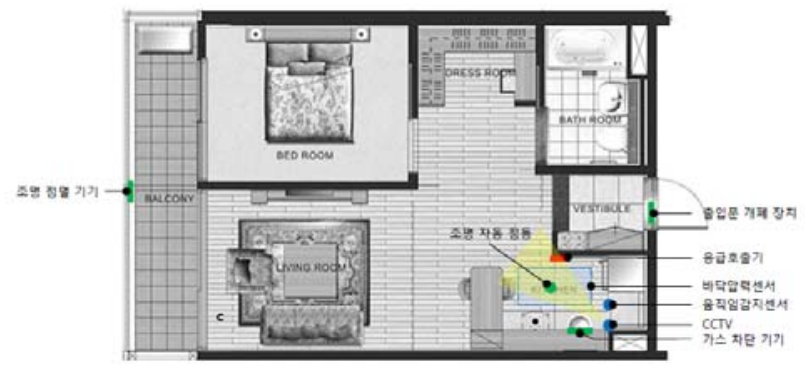

Fig. 1. An exemplary organization of sensors and instruments for the intelligent service for managing solitary fall death.

\section{Intelligent SERVice for Managing Solitary Fall DEATHS}

\section{A. Organization of Sensors and Instruments for Intelligence Service for Managing Solitary Fall Deaths}

An appropriate post-fall management should be provided through fall detection monitoring. A fall, which is not immediately followed by a prompt response, may lead to a solitary death, so adequate post-accident services such as emergency call and indoor environment adjustment should be supported. For such post-accident services, various sensors and instruments can be employed. To ensure an operation that is efficient in terms of cost and management, however, it should be desirable to use smallest possible number of sensors and instruments. In this light, Fig. 1 shows the organization of sensors and instruments needed for fall detection, indoor environment adjustment, and emergency call, as required for post-accident management designed to prevent solitary fall deaths.

When we analyzed the behaviors of elderly people who lived alone in Chapter 3, the behavior in the kitchen registered the highest frequency, while "meal preparation and kitchen arrangement - dining" showed as the major behavioral pattern. Therefore, it is desirable to monitor resident behaviors while considering the line of movement for the major behavioral patterns focusing on the kitchen, a high-frequency space. Fig. 1 shows an exemplary arrangement of CCTV, motion detection sensor, floor pressure sensor, and emergency caller required to report emergency situations as needed for fall detection monitoring, and lighting switch, light flasher, door open/close system, and gas stopper as needed for indoor environment adjustment service, both in consideration of the major behavioral pattern pivoting on the kitchen ("meal preparation and kitchen arrangement - dining").

First, CCTV and motion detection sensor, which are needed for fall detection monitoring, are going to be installed on the ceiling that detects resident behavior well, lying on the line of movement that leads to 'cooking space and table' in the kitchen, while taking into account of the line of movement of the major behavioral pattern of elderly people who live alone ("meal preparation and kitchen arrangement dining"). And the floor pressure detector shall be installed on the floor along the line of movement that leads to 'cooking space and table'. Second, emergency caller, which is used to alert emergency situations, is an indispensable device. As it is activated by a user, the device has to be installed within 50 to $80 \mathrm{~cm}$, a height reachable by hands from a supine position after a fall in the kitchen. Lastly, environmental factors must be able to be controlled through indoor environment adjustment service. When a resident, who is involved in 'meal preparation and kitchen arrangement - dining', suffers a fall, it is probably while cooking on a gas stove. When such an accident occurs, the gas stopper activates to prevent secondary accidents such as gas leak, fire, and explosion. Thus, it helps secure field of vision needed to respond to emergency situations following a fall. Light switch, recognizing a fall through fall detection monitoring, automatically turns on the general diffused lighting indoor. Auto light flasher, installed outside to help people easily locate the accident, effectively alerts the specific emergency situation to people outside. And the door open/close system is necessary to allow rescuers promptly go into the house in an emergency situation.

It is an important research topic how to put sensors in appropriate locations fitting the purpose of objects that they are respectively designed to detect. Because early studies on sensor location are unsatisfactory, however, active research is needed in that regard. In this paper, we have suggested an organization of sensors and instruments, which considers the line of movement foR the major behavioral pattern ('meal preparation and kitchen arrangement - dining') that pivots on the kitchen, a space most used in the house by solitary elderly people. As scope of application varies with sensor performance and type, however, it is important to consider sensor characteristics in arranging them to make sure that they efficiently detect target objects. And sensors that are installed in the house are hard to maintenance and repair, their application to various services requires adoption of flexible sensors that may be effectively used in any structure. To provide intelligent services using such sensors, they must support wireless network technology that is suitable in ubiquitous environment. And sensors to be used in the house for elderly people who live alone must be reasonably priced and low-wattage, since they are applied in small-sized houses [22].

\section{B. Process of Service for Managing Solitary Fall Deaths}

The services for managing solitary fall deaths of elderly people who live alone are divided into pre-fall and post-fall services. This paper has the kernel of the study as 
development of post-accident management service. With timely post-accident management through fall detection monitoring, solitary fall deaths can be prevented and managed. Fig. 2 shows the process of the service for managing solitary fall deaths.

As shown in Fig. 2, when a resident suffers a fall in the house, various sensors and instruments detect signs of abnormality. Fall detection monitoring is performed by CCTV, motion sensor, and floor pressure sensor. Once fall detection monitoring identifies a fall, emergency call and indoor environment adjustment service provide solitary fall death management service. First of all, it notifies the resident' $s$ family or helper of the fall. Family or helper can asks emergency center or local community center, and if family or helper does not respond, emergency call is placed directly to emergency medicine center or local community center for a response to the specific emergency situation. A resident may act on his or her own to ask family, helper, emergency medicine center, or local community center for help. Indoor environment adjustment service must be able to control the environmental factors through indoor environment adjustment service to keep the resident' $\mathrm{s}$ condition from further deteriorating until his or her rescue. For example, in case a resident falls while using the gas stove in the kitchen, the gas stopper activates to prevent bigger accidents such as gas leak, fire, and explosion. Light switch secures field of vision for a response to an emergency situation by automatically turning on general diffused lighting in the house. Automatic light flasher is to be installed on the exterior wall to facilitate location of an accident by people coming from outside, and can be used as a tool for alerting emergency situations. And, door open/close system is necessary to ensure a rescuer's prompt entry into the house in an emergency situation.

We have suggested an organization and process of services for managing solitary fall deaths by focusing on the kitchen based on the results of the study that came up with major behavioral patterns. While proposing such organization and process of the services, the thesis has assumed that services should focus on areas with high behavioral frequency. Yet, high behavioral frequency cannot lead to a high fall probability. For falls can be likelier with low behavioral frequency. It is logical for this thesis to focus on behavioral pattern in suggesting an organization of services, but focusing on behavioral patterns also constitutes its limitation. Future studies should need systematic research as to the correlation between physical environment, behavioral frequency, and falls. While this paper does not give sufficient treatment to physical environment that considers spatial dimensions or space itself, the results of the behavioral analysis extracted in this thesis have provided grounds for the organization and arrangement of sensors and instruments. This thesis is significant in that it suggests an organization of sensors while considering behaviors from the perspective of a resident. Future studies will have to continue in developing residential services that prevent solitary deaths by upgrading self-administered questionnaire to collect various behavioral data and monitoring accidents including falls in the house through an indoor network of devices. Such studies would enable development of individually customized services that consider resident behavior.

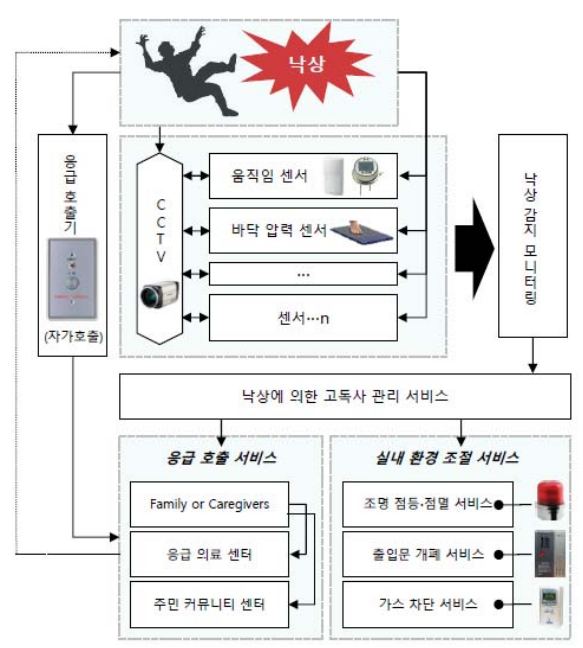

Fig. 2. Summary of behavioral patterns and space usage pattern.

\section{CONCLUSION}

In this paper, we have described the method for organizing intelligence services for managing solitary fall deaths with a focus on the kitchen that urgently requires management by analyzing frequency-based major behavioral patterns on the basis of self-administered questionnaire, in order to figure out behaviors shown in the house by elderly people who live alone. We zeroed in on analysis of resident behaviors with the purpose of developing resident-focused services. In figuring out behaviors in the house involving elderly people who live alone, the 24-hour self-administered questionnaire is significant in that it has provided grounds for providing customized services for elderly people. Yet, the study has limitations in that it hasn't tested the fidelity of the performance on the 24-hour self-administered questionnaire. And we have complemented the insufficiency by providing causes of falls and predicting falls while considering the circumstances before and after the behavioral patterns involving a resident and analyzing the causes of falls involving elderly people based on related research literature. And by focusing on the kitchen with the highest frequency to organize sensors and instruments needed for an intelligent service, we have kept an eye on economy and ease of construction. To prevent elderly people who live alone from suffering a solitary fall death, a minimum number of sensors should be used and a focus must be given to post-fall emergency situations in presenting an organization of an intelligent service. This paper is significant in that it suggests specific services while applying IT in the issue of solitary fall death and by focusing on falls.

Smart Home can create a safe and pleasant life for elderly people. The new IT-related services developed and distributed so far are oriented to younger generations. Employment of IT could improve the quality of life for elderly people, achieving effectiveness in ensuring their security and preventing accidents. Elderly people' s safety management services should also address their lifestyles such as resident behaviors, habits, and values. In this paper, by 
considering resident lifestyles and proposing an optimized intelligent service designed to prevent and manage solitary fall deaths, we have shown that we can upgrade the quality of life for elderly people who love alone through upgrade of indoor environment and emotional security from awareness of protection. An intelligent service, which is appropriate for behaviors and requirements involving elderly people who live alone with emergency monitoring, emergency alert, emergency aid/call system, detection sensors, and home network, is advantageous to solve the issue ageing. We expect that this will successfully address the issue of solitary death by reducing the financial burden related to the method for checking safety for elderly people who live alone and planning and creating such a service in housing. As it is deeply related to human dignity, solitary death must be addressed by our society. Solitary death can be successfully handled through an approach that deploys not only staff but also IT convergence. In this paper, we have suggested that IT-applying services should be used in post-fall management and that physical environment is crucial in preventing falls. Thus, the focus of the thesis lies on post-fall management. To decrease falls, plans for preventing them are necessary. We think that further research is needed on IT environment as well as physical environment with a view to fall prevention.

\section{ACKNOWLEDGMENT}

This work was supported by the National Research Foundation of Korea (NRF) grant funded by the Korea government (MSIP). (No. 2008-0061908)

\section{REFERENCES}

[1] M. Motoki, Community Building without Kodokushi, 2008, Tokyo: Diamond Inc. 2008.

[2] Y. Fukukawa, "Solitary death: a new problem of an aging society in Japan," Social Science \& Medicine, vol. 59, no. 1, pp. 174-185. 2011.

[3] L. W. Guse and M. A. Masesar, "Quality of life and successful aging in long-termcare: perceptions of residents," Issues in Mental Health Nursing, vol. 20, pp. 527-539. 1999.

[4] B. M. Cox, "Linking housing and services for low income elderly," Journal of Housing for the Elderly, vol. 15, pp. 97-110. 2001.

[5] M. E. Tinetti, M. Speechley, and S. F. Finter, "Isk factors for falls among elderly persons living in the community," The New England Journal of Medicine, vol. 319, pp. 1701-1707, 1998.

[6] P. A. H. C. Statistics Korea. (2010). [Online]. Available: http://www. ccn.go.kr/board2/board.ccn?gSiteCode $=2 \&$ gMenuCode $=5 \&$ nMenuC ode $=18 \&$ boardCode $=220 \&$ mode $=$ view\&boardSeq $=1162322$

[7] L. H. Soo, P. S. Joon, and J. J. Ye, "A Study on development of an Intelligent residential service based on elderly people's behavioral patterns," Architectural Institute of Korea, vol. 28, no. 5, pp. 159-168. 2012.

[8] A. M. Bernstein and C. L. Schur, "Expenditures for unintentional injuries among the elderly," Journal of Aging and Health, vol. 2, no. 157, pp. 157-178. 1990.

[9] D. Covington, J. Maxwell, and T. Clancy, "Hospital resources used to treat the injured elderly at north carolina trauma centers," Journal of the American Geriatrics Society, vol. 41, no. 8, pp. 842-852,1993.

[10] J. A. Grisso, D. F. Schwarz, D. Wolfson, M. Polansky, and K. Lapenn, "Impact of falls in an inner-city elderly african-american population,"
Journal of the American Geriatrics Society, vol. 40, no. 7, pp. 673-678. 1992.

[11] B. A. Alexander, F. P. Rivara, and M. E. Wolf, "The cost and frequency of fall-related injuries in older adults," American Journal of Public Health, vol. 82, no. 7, pp. 1020-1023. 1992.

[12] K. S. Gyeong, "A Study on risks for falls in the elderly and occupational therapy for prevention purpose," Korean Association of Occupational Therapists, vol. 13, no. 3, pp. 69-76. 2005.

[13] M. Hunhammar, "The development of it-supported residential Services: a conceptual model of influences and constraints," Utomation in Construction, vol. 5, no. 5, pp. 499-510, 1997.

$\begin{array}{lll}\text { [14] Doopiedia. } & \text { (2013). Available: }\end{array}$ http://www.doopedia.co.kr/doopedia/master/master.do?_method=vie w\&MAS_IDX=140106001421178

[15] L. J. Hyeon and L. H. Soo, "Development of a model for inference and recognition with a view to a ubiquitous residential environment," The Korea Institute of Electronic Communication Sciences, vol. 24, no. 2, pp. 138-148. 2008.

[16] G. Demiris and B. Hensel, "Smart homes" for patients at the end of life," Journal of Housing for the Elderly, vol. 23, no. 1, pp. 106-115. 2009.

[17] H. Lee, P. S. J, M. Kim, J. Jung, H. W. Lim, and J. T. Kim, "The service pattern-oriented smart bedroom based on elderly spatial behaviour patterns," Ndoor and Built Environment, vol. 22, no. 1, pp. 299-308. 2013.

[18] Time Use Survey. (2004). [Online]. Available: whttp://www. lib1.kostat.go.kr/search/detail/CATTOT000000041846

[19] O. C. D. B. F. Eamonn, "Studying the natural history of behavior," Psychologist, vol. 21, no. 12, pp. 1034-1036. 2008.

[20] O. G. Santin and L. Ltard, "Occupants' behavior: determinants and effects on residential heating consumption," Building Research \& Information, vol. 38, no. 3, pp. 318-338. 2010.

[21] L. Soo, Analysis of the Correlation between Demographic Characteristics and Behaviors of Elderly People, Yonsei University: Seoul, 2013.

[22] L. H. Jae, L. H. Taek, and S. H. Sik, "A study of ubiquitous sensor network technology," The Korea Institute of Electronic Communication Sciences, vol. 4, no. 1, pp. 70-77. 2009.

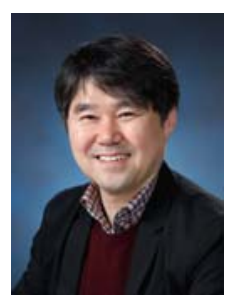

Hyun Soo Lee received his Ph.D in the key centre of design computing and cognition (the Faculty of Architecture) at the University of Sydney, Sydney, Australia in 2007. He received the B.S. degree in architectural engineering from Yonsei University. He has been currently a professor of the Department of Interior Architecture and Built Environment since 1993. He directed interior design of Yonsei University Songdo Campus in 2007. He acts as the president of Korean Society Modern Han-ok. Also, he is currently a Eunpyeong-gu MP, Neighborhood Village Master plan using User's Participation Approach in 2013. His research interests have spanned various areas of housing and interior design including healthy housing, modern han-ok, behavior-based elderly housing, spatial place marketing, environmental color design and mixed-use building. Lately he has started research work in the Smart Home towards the Sustainable Healthy Housing. Professor Lee has been developing life-log data oriented smart services in association with resident's various life style management items according to residents' needs and machine learning methods.

Sung Hee Lee received her bachelor in the Catholic University of Korea and master in the Department of Interior Architecture and Built Environment at Yonsei University, Seoul, Korea. During the bachelor course, she was trained as a designer through design studio courses, and for the master course, she undertook research in the area of housing. 